\title{
EFEKTIFITAS MEDIA ONLINE YANG DIGUNAKAN DALAM PROSES PEMBELAJARAN DARING
}

\author{
Aziz Kurniawan \\ IAIN Purwokerto, Purwokerto \\ Azizkurniawan0705@gmail.com
}

\begin{abstract}
The covid-19 pandemic era forced teachers and educators to apply learning by applying online models. Many platforms are offered to facilitate learning, of course it confuses what application is suitable to use so that learning continues to run well even with the online system. So the purpose of this study is (1) to know the understanding and interest of students after learning by using online media platform, (2) to know the effectiveness of the platform that is often used during emergencies Covid-19, (3) able to implement a suitable platform for learning during pandemic Covid-19. This study uses a descriptive qualitative method. where in research the data obtained is then interpreted by the researcher. Based on the results obtained that the use of $W A G$ as a single medium in learning is less effective, while the use of the classroom can be said to be effective because it is applied to students become more active in learning while the google meet application provides effective results in learning because learners are able to directly understand the material brought but has some constraints faced especially in signals and quotas. So it is necessary to use a combination of teleconference applications such as google meet and applications such as WAG / Classroom as a discussion container
\end{abstract}

Keywords: Effectiveness, Online Media, Online Learning

\begin{abstract}
Abstrak : Masa pandemic covid-19 memaksa para guru dan tenaga pendidikan untuk menerapkan pembelajaran dengan menerapkan model daring. Banyak platform yang ditawarkan agar memudahkan dalam pembelajaran, tentunya hal tersebut membuat bingung aplikasi apa yang cocok digunakan agar pembelajaran tetap berjalan dengan baik walaupun dengan sistem daring. Maka tujuan dari penelitian ini yaitu (1) mengetahui pemahaman dan minat mahasiswa setelah pembelajaran dengan menggunakn platform media online, (2) mengetahui efektivitas dari platform yang sering digunakan dimasa darurat Covid-19, (3) mampu menerapkan platform yang cocok untuk pembelajaran dimasa pandemic Covid-19. Penelitian ini menggunakan metode kualitatif deskriptif. dimana dalam penelitian data yang diperoleh kemudian dijabarkan oleh peneliti. Berdasrkan hasil yang diperoleh yaitu penggunaan WAG sebagai media tunggal dalam pembelajaran kurang begitu efektif, sedangkan penggunaan classroom bisa dikatakan efektif karena diaplikasi tersebut mahasiswa menjadi lebih aktif dalam pembelajaran sedangkan aplikasi google meet memberikan hasil yang efektif dalam pembelajaran karena peserta didik mampu memahami secara langsung materi yang dibawakan tetapi memiliki beberapa kendala yang dihadapi terutama dalam sinyal dan kuota. Maka perlu menggunakan gabungan aplikasi teleconference seperti google meet dan aplikasi seperti WAG/Classroom sebagai wadah diskusi.
\end{abstract}

Kata Kunci: Efektifitas, Media Online, Pembelajaran Daring 


\section{PENDAHULUAN}

Akhir Desember 2019 Kota Wuhan, China menjadi sorotan dunia karena menjadi kota dan Negara pertama kali mengumumkan adanya penyebaran wabah penyakit baru yaitu Corona Virus Disease 2019 atau yang sering kita sebut sebagai Virus Covid 19 (Yunus $^{1}$ dan Rezki, 2020). Dalam waktu yang singkat penyebaran Virus Covid 19 yang awalnya terdapat di kota Wuhan kini telah tersebar sampai keseluruh dunia. Hingga diawal bulan Maret 2020 Indonesia mengumumkan adanya kasus pertama Covid 19 di Indonesia (Hanoatubun², Silpa. 2020).

Seluruh dunia kini telah menerima dampak dari virus Covid 19 baik dibidang industri, ekonomi bahkan pendidikan pun mengalami imbasnya (Burhanuddin ${ }^{3}$, Chairul Iksan dan Muhammad Nur Abdi, 2020). Indonesia termasuk dari salah satu negara yang mengalami dampak dari wabah virus Covid 19. Banyak upaya yang telah dilakukan pemerintah agar pemutusan virus covid 19 cepat berakhir. Salah satunya dengan menerapkan phsycal distancing, ibadah dirumah serta menerapkan WFH (work from home) bagi para pekerja baik swasta maupun negeri (Kresna ${ }^{4}$, Arif., dan Juni Ahyar, 2020). Bagi tenaga pendidik baik guru maupun dosen dengan penerapan program WFH tentunya mengalami kendala yang teramat besar karena proses pembelajaran tidak memperbolehkan dilaksanakan secara offline.

Jauh sebelumnya, perkembangan teknologi di abad ini memiliki pengaruh besar dalam berbagai bidang, Salah satunya dalam bidang komunikasi. Kemajuan bidang komunikasi memudahkan manusia dalam menerima dan mengirim informasi. Pada bidang Pendidikan dengan kemajuan teknologi saat ini melahirkan beberapa solusi dalam pembelajaran yang awal mulanya pembelajaran hanya diterapkan secara tatap muka langsung dan berada diruang kelas kini belajar bisa diterapkan melalui

\footnotetext{
1 Yunus, N. R., \& Rezki, A. "Kebijakan Pemberlakuan Lock Down Sebagai Antisipasi Penyebaran Corona Virus Covid-19”. Salam: Jurnal Sosial Dan Budaya Syar-I, 7 (3), 2020, hal 227-238

${ }^{2}$ Hanoatubun, Silpa. "Dampak Covid-19 Terhadap Perekonomian Indonesia." EduPsyCouns Journal. 2 (1), 2020, hal 146-153

${ }^{3}$ Burhanuddin, Chairul Iksan dan Muhammad Nur Abdi. "Ancaman Krisis Ekonomi Global Dari Dampak Penyebaran Virus Corona (Covid 19)" AkMen Jurnal Ilmiah 17(3), 2020, hal 90-98

${ }^{4}$ Kresna, Arief., dan Juni Ahyar. "Pengaruh Physical Distancing dan Sosial Distancing Terhadap Kesehatan dalam Pendekatan Linguistik”. Jurnal Syntax Tranformation. 1 (4). 2020, hal 14-19
} 
kelas virtual yang bisa diakses dimana saja. (Zhafira ${ }^{5}$, dkk . 2020) menjelaskan pembelajaran daring intinya pembelajaran bisa dilakukan walaupun tanpa mengharuskan siswa untuk hadir dalam kelas dengan memanfaatkan internet.

Inti dari pembelajaran daring merupakan proses pembelajaran yang menekankan pada pemanfaatan teknologi sebagai sarana belajar. Pada awalnya pembelajaran dengan mengunakan daring diharapkan siswa atau mahasiswa memiliki kemampuan dalam mengoprasikan computer, namun sejalannya waktu pembelajaran daring juga mampu digunakan melalui perangkat berupa HP (Kuntarto ${ }^{6}$, Eko. 2017). Proses pembelajaran dimasa pandemik ini memaksa bagi guru dan dosen agar lebih kreatif dalam melaksanakan Pendidikan. Walaupun proses pembelajaran tidak dilaksanakan secara offline atau tatap muka langsung kegiatan pembelajaran harus tetap berlangsung. Oleh karena itu banyak platform yang menawarkan fitur-fitur menarik agar pembelajaran tetap berlangsung (Kusuma ${ }^{7}$, Jaka Wijaya., dan Hamidah. 2020). Indiani ${ }^{8}$, baroroh (2020) menjelaskan bahwa banyaknya platform yang ditawarkan tentunya memiliki tujuan yang sama yaitu agar pembelajaran daring mampu menghasilkan output yang semaksimal mungkin dalam pembelajaran.

Menelisik banyaknya tawaran aplikasi yang digunakan untuk membantu guru atau dosen dalam melakukan proses belajar. Peneliti tertarik akan seberapa besar Efektifitas Media Online yang digunakan dalam Proses Pembelajaran Daring yang sering digunakan sebagai sarana belajar peserta didik. Media yang sering digunakan yaitu Whatsapp Group, Google Classroom,dan Google Meet

${ }^{5}$ Zhafira, N.H., dkk. Persepsi Mahasiswa Terhadap Perkuliahan Daring Sebagai Sarana Pembelajaran”. Jurnal Bisnis dan Kajian Strategi Manajemen. 4 (1), 2020, hal 37-45

${ }^{6}$ Kuntarto, Eko. "Keefektifan Model Pembelajaran Daring dalam Perkuliahan Bahasa Indonesia di Perguruan Tinggi”. Journal Indonesian Language Education and Literature. 3 (1). 2017, hal 99-110

${ }^{7}$ Kusuma, Jaka Wijaya., dan Hamidah. "Perbandingan Hasil Belajar Matematika dengan Menggunakan Platform Whatapp Grup dan Webinar Zoom dalam Pembelajaran Jarak Jauh pada Masa Pandemik Covid 19”. Jurnal Ilmiah Pendidikan Matematika. 5 (1). 2020, hal 97-106

8 Indiani, Baroroh. 2020. "Mengoptimalkan Proses Pembelajaran Dengan Media Daring Pada Masa Pandemi COVID-19”. Jurnal Sipatokkong BPSDM Sulawesi Selatan. 1 ( 3), 2020, hal 227-232 


\section{METODE PENELITIAN}

Rangkaian penelitian yang diterapkan merupakan rangkaian dari penelitian kualitatif deskriptif. dimana dalam penelitian ini data yang diperoleh kemudian dijabarkan oleh peneliti. Data yang diperoleh melalui penyebaran angket yang dibagikan pada google formulir yang kemudian di isi oleh mahasiswa bisa melalui komputer atau HP. Jumlah responden yang telah mengisi dalam penelitian ini sejumlah 97 mahasiswa pada program studi PGMI di mata kuliah IPA Fisika, Kimia dan Alam semesta yang terdiri dari 3 kelas dengan menggunakan platform yang berbeda-beda. Selain angket peneliti juga melakukan wawancara terhadap beberapa mahasiswa secara random terkait keuntungan dan kendala yang dihadapi saat penggunaan media yang digunakan sebagai media pembelajaran daring.

Isi instrumen yang disebarkan merupakan serangkaian pertanyaan yang diperoleh dari hasil pengalaman mahasiswa selama mengikuti perkuliahan daring dari bulan September 2020 hingga akhir Oktober 2020.

\section{HASIL DAN PEMBAHASAN}

\section{Daring dengan platform Whattapps Grup (WAG) di Kelas 3 PGMI C}

Whattapps merupakan aplikasi messenger pada smartphone yang digunakan untuk komunikasi dengan memanfaatkan internet (Indraryani ${ }^{9}$, Eka \& Dwi Suliworo. 2018). Awalnya penggunaan whattaps diperuntukan untuk berbagi pesan namun dengan berkembangnya teknologi whattapps menambah fitur seperti berbagi suara, gambar dan video bahkan sekarang bisa digunakan untuk videocall. Hampir seluruh masyarakat mengenal akan aplikasi whatapps, seiring dengan masa pandemi yang melanda di seluruh dunia akhirnya penggunaan whattaps yang awalnya digunakan sebagai media komunikasi beralih menjadi media pembelajaran daring.

Pembelajaran dengan menggunalan WAG sebagai media berkomunikasi sekaligus berdiskusi dengan mahasiswa. Pada awal pembelajaran mahasiswa

\footnotetext{
${ }^{9}$ Indaryani, Eka \& Eka Suliworo. 2018. "Dampak pemanfaatan Whats App dalam meningkatkean motivasi belajar siswa pada pelajaran fisika”. Seminar Nasional Quantum (pp 2477-1511). Yogjakarta: Universitas Ahmad Dahlan
} 
mengirimkan makalah dan PPT pada WAG. Setelah mengirim materi, kelompok yang melakukan presentasi menggunakan voicenote dan mahasiswa lainnya mengomentari dan berdiskusi terkait materi yang disampaikan tersebut. Berikut besar pemahaman belajar mahasiswa dalam menggunakan platform WAG dapat dilihat pada gambar 1 berikut ini :

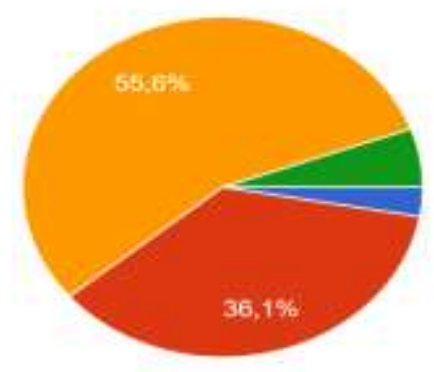

Sangat Paham

Paham

Kurang Paham

Tidak Paham

Gambar 1. Diagram Pemahaman Belajar mahasiswa dengan WAG

Berdasarkan data gambar 1 diperoleh bahwa persentase pengalaman mahasiswa selama mengikuti perkuliahan dengan menggunakan WAG 2,8\% atau sebanyak 1 mahasiswa mengatakan dengan menggunakan WAG pemahamanya sangat paham. 36,1\% atau sebanyak 13 mahasiswa pemahaman belajar dengan WAG dengan kategori paham, 55,6 \% atau sebanyak 20 mahasiswa mengatakan tidak begitu paham dengan materi yang dibahas dan 5,6\% atau 2 mahasiswa tidak paham pembelajaran via WAG. Masih banyaknya presentase mahasiswa yang tidak begitu paham dengan menggunaan WAG sebagai media belajar tentunya memiliki pengaruh yang besar terutama pada hasil output dari perkuliahan itu sendiri.

Karena pemahaman mahasiswa terkait materi perkuliahan banyak yang kurang, maka hal tersebut juga mengakibatkan minat akan mahasiswa dalam belajar juga banyak yang kurang. Data tersebut dapat dilihat melalui gambar 2 berikut: 


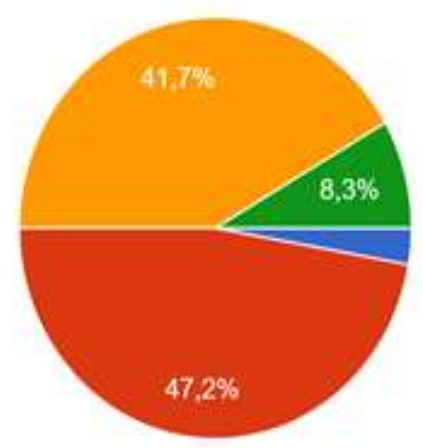

setelah pembelajaran minat belajar saya sangat baik

setelah pembelajaran minat belajar saya baik

setelah pembelajaran minat belajar saya kurang baik

setelah pembelajaran minat belajar saya tidak baik

Gambar 2. Diagram Minat Belajar Mahasiswa dengan WAG

Gambar 2 menerangkan sebanyak 2,8\% atau 1 mahasiswa minat belajar mahasiswa sangat baik, 47,2\% atau 17 mahasiswa minat belajar baik, 41,7\% atau 15 mahasiswa setelah pembelajaran minat akan belajar kurang baik dan 8,3 $\%$ atau 3 mahasiswa kategori minat belajar tidak baik atau sangat kurang. Data tersebuat menjelaskan bahwa WAG kurang begitu efektif jika diterapkan sebagai media pembelajaran di masa pandemi.

Hal tersebut sejalan dengan hasil penelitian (Daheri ${ }^{10}$, Mirzon., dkk. 2020) bahwa penggunaan whatapps tidak begitu efektif jika digunakan dalam pembelajaran karena dalam guru menjelaskan kurang begitu dimengerti oleh siswa. Sedangkan menurut peneliti sendiri kurang efektifnya WAG dikarena dalam menjelasan ruang gerak dosen dalam menjelaskan menjadi sangat terbatas, selain itu penjelasan dosen di WAG sering tertindih dengan chat mahasiswa lainnya yang membuat mahasiswa menjadi bingung.

${ }^{10}$ Daheri, Mirzon., dkk. "Efektifitas Whats App sebagai Media Belajar Daring” Jurnal Basicedu: Journal of Elementary Education. 4(4). 2020, Hal 775-783 


\section{Daring dengan platform Google Classroom di Kelas 3 PGMI A}

12 Agustus 2014 Google Classroom mulai dirilis, aplikasi tersebut merupakan produk dari google. Menurut wicaksono ${ }^{11}$ (2020) penggunaan classroom diperuntukan untuk guru dan siswa agar terhubung baik dalam atau luar sekolah, memudahkan untuk guru dalam pengorganisasian kelas serta memudahkan dalam bidang pengajaran. Pemanfaatan Google Classroom diharapkan mampu memberikan manfaat kepada mahasiswa untuk melatih aspek kognitif, afektif dan psikomotorik (Harefa, Nelius \& Sumiyati $\left.{ }^{12}, 2020\right)$.
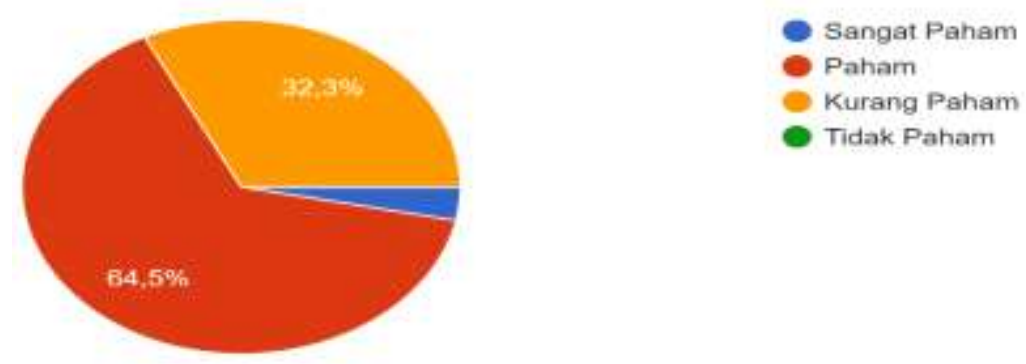

Gambar 3. Diagram Pemahaman Belajar Mahasiswa dengan Classroom

Pada gambar 3 menjelaskan pemahmaan mahasiswa selama mengikuti kegiatan pembelajaran di masa pandemic dengan menggunakan platform Google Classroom sebagai berikut: sebanyak 10 mahasiswa atau 32,3\% mengatakan bahwa pemahaman mereka terkait pembelajaran melalui via classroom kategori kurang paham . 20 mahasiswa atau 64,5 \% mengatakan bahwa selama pembelajaran dengan classroom pemahaman mereka baik dan 3,2\% atau 1 mahasiswa setelah pembelajaran pemahamannya terkait materi kategori sangat paham.

Pengalaman mahasiswa selama belajar menggunakan classroom tersebut tentunya menimbulkan bagaimana minat belajar mahasiswa setelah pembelajaran usai atau yang akan dating. Untuk menjawab pertanyaan tersebut tentunya

\footnotetext{
${ }^{11}$ Wicaksono, M. D. "Pemanfaatan Google Classroom dalam Strategi Pembelajaran Kooperatif pada Mata Pelajaran Ips Kelas VIII”. Inspirasi (Jurnal Ilmu-Ilmu sosial),17(1), 2020, hal 234-242

12 Harefa, Nelius \& Sumiyati. "Persepsi Siswa Terhadap Google Classroom sebagai LMS pada masa Pandemi Covid-19”. Science Education and Application Journal (SEAJ) 2(2). 2020, Hal 88-100
} 
diperlukan data terkait minat belajar mahasiswa dalam belajar dengan menggunakan classroom yang akan ditampilkan pada gambar 4 sebagai berikut :

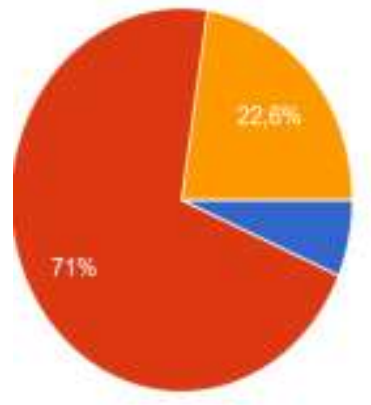

Gambar 4 Diagram Minat Belajar Mahasiswa dengan Classroom

Diagram minat belajar mahasiswa dengan menggunakan classroom yang tertuang pada gambar 4 sebagai berikut: 7 mahasiswa atau 22,6\% setelah pembelajaran minat belajar masuk dalam kategori kurang, 22 mahasiswa atau 71 $\%$ setelah pembelajaran minat akan belajar mendatang untuk pembelajaran minggu depan masuk dalam kategori baik dan 2 mahasiswa atau 6,5\% setelah pemelajaran minat akan belajar terkait materi minggu depan dengan menggunakan classroom termasuk kategori sangat baik. Berdasarkan gambar diagram tersebut dapat ditarik kesimpulan bahwa lebih dari $75 \%$ menjelaskan minat belajar mahasiswa akan belajar dengan classroom lebih baik daripada pembelajaran dengan via WAG.

Sidik, dkk ${ }^{13}(2019)$ menjelaskan dengan menggunakan classroom siswa mampu meningkatkan pemahaman dalam belajar karena dengan menggunakan aplikasi ini siswa dituntut menjadi aktif dalam proses belajar sehingga pengetahuan yang didapat berdasarkan pengalaman mereka langsung yang terlibat dalan proses belajar. Selain itu, penggunaan aplikasi google classroom tidak begitu rumit sejalan dengan penelitian Rosita, Nur dkk ${ }^{14}$ (2019) mengatakan

13 Sidik, Irwan Fariza., Mohd Mahzan Awang \& Abdul Razaq Ahmad. "The Relationship between Students' Involvement in $21^{\text {st }}$ Century Classroom Learning Activities and Higher Order Thinking Skills". Jurnal Pendidikan Malaysia 44(1). 2019, hal 59-64

${ }^{14}$ Rosita, Nur., Saunir Saun \& Salam Mairi. "Google Classroom for Hybrid Learning in Senior High School”. Journal of Learning and Teaching in Digital Age. 5(1), 2019, hal 35-41 
bahwa pembelajaran dengan classroom sangat mudah digunakan karena fiturfitur yang ada tidak membuat pengguna bingung,

\section{Daring dengan platform Google Meet di Kelas 3 PGMI D}

Pada gambar 5 menggambarkan pemahaman mahasiswa selama mengikuti perkuliahan dengan menggunakan aplikasi google meet sebanyak 25 mahasiswa atau $78,1 \%$ memiliki pemahaman yang baik setelah melakukan pembelajaran dan 7 mahasiswa atau 21,9\% mengatakan pemahaman kurang baik. Data tersebut digambarkan pada gambar 5 berikut:

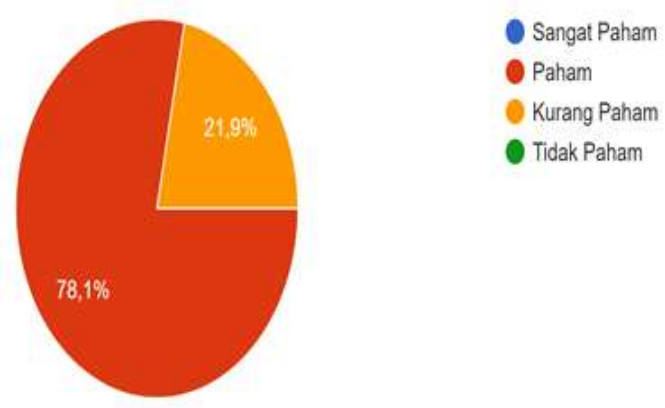

Gambar 5. Diagram Pemahaman Belajar Mahasiswa dengan Google Meet

Setelah melihat besar pemahaman mahasiswa dalam menerima materi dengan menggunakan via google selanjutnya peneliti ingin mengetahui besaran minat belajar mahasiswa dalam mengikuti proses pembelajaran untuk minggu depan sebagai berikut 10 mahasiswa atau 31,3\% minat belajar masuk dalam kategori kurang baik, 21 mahasiswa atau 65,6 \% masuk dalam kategori baik dan 1 mahasiswa atau 3,1\% masuk dalam kategori sangat baik. Data tersebut tergambarkan dalam diagram sebagai berikut: 


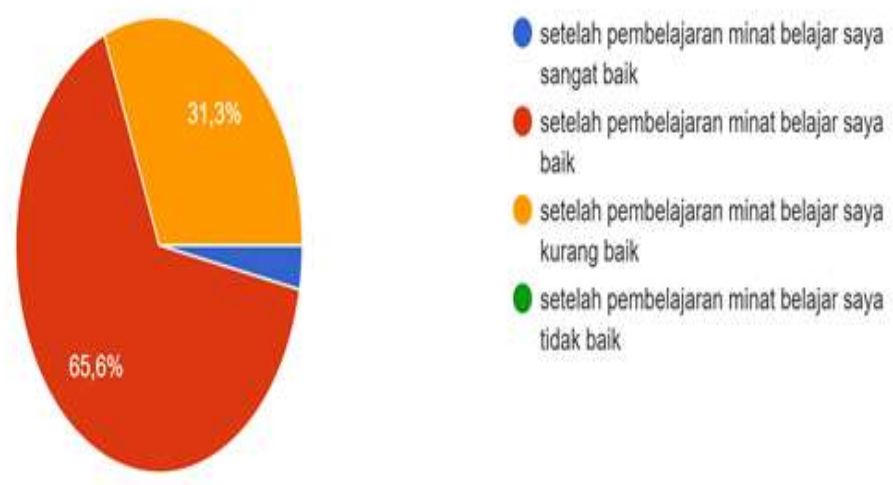

Gambar 6. Diagram Minat Belajar Mahasiswa dengan Google Meet

Irmawanty, $\mathrm{dkk}^{15}$ (2020) penggunaan aplikasi google meet sebagai media dalam pembelajaran bisa dikatakan baik hal ini karena dalam pelaksanaan penggunaan apliasi google meet mampu mendampingi proses pembelajaran secara langsung walapun melaui virtual. Pada aplikasi google meet terdapat fitur yang menarik seperti kolom chat dimana mahasiswa bisa berkomunikasi langsung kepada seluruh peserta yang hadir dalam google meet. Jumlah pengguna dalam satu forum bisa mencampai 100 partisipan (Fuadi, Tuti Marjan., dkk ${ }^{16}$. 2020). Selain itu terdapat fitur berupa share screen dimana presenting bisa mempresentasikan langsung materi kepada seluruh partisipan google meet.

Berdasarkan pengalaman mahasiswa selama mengikuti perkuliahan dengan menggunakan google meet terdapat beberapa kendala dalam penggunaan yaitu : mahasiswa cenderung mengatakan dengan menggunakan google meet kuota mahasiswa menjadi boros dari aplikasi WAG maupun Classroom, selain itu kendala sinyal juga menjadi kendala yang perlu diperhatikan karena terkadang dalam pembelajaran mahasiswa kesulitan menerima sinyal yang baik hal ini berakibat pada penjelasan materi pada google meet menjadi terputus-putus

15 Irmawanty., Mohamad Syarif Sumantri., M. Japar "Pendampingan Penulisan Karya Ilmiah (KTI) pada Guru Madrasah Ibtidaiyah secara Online dengan Menggunakan Google Meet”. Prosiding Seminar Nasional Pascasarjana Universitas Negeri Jakarta. 1(1), 2019, hal 146-153

16 Fuadi, Tuti Marjan., Riki Musriandi., Linda Suryani. "Covid-19: Penerapan Pembelajaran Daring di Perguruan Tinggi” :Jurnal Dedikasi Pendidikan, 4 (2). 2020, hal 193-200 


\section{KESIMPULAN}

Berdasarkan hasil dan pembahasan diatas dapat disimpulkan bahwa pembelajaran yang dilaksanakan di masa pandemi ini maka diperlukan pemilihan aplikasi dalam membantu pembelajaran yang tepat agar pembelajaran berjalan dengan baik. Pemilihan aplikasi ini diharapkan mampu memberikan output berupa pemahaman mahasiswa setelah pembelajaran menjadi baik serta minat belajar menjadi meningkat walapun pembelajaran dilaksanakan via daring.

Penggunaan WAG sebagai sarana tunggal dalam belajar belum memberikan hasil yang memuaskan hal ini terjadi karena ruang gerak dosen dalam menjelaskan menjadi terbatas sedangkan penggunaan classroom sebagai sarana belajar mampu memberikan kesempatan kepada mahasiswa untuk aktif sehingga pengetahuan yang didapat berdasarkan pengalaman langsung yang didapat melalui aplikasi google classroom.

Aplikasi google meet merupakan salah satu aplikasi telekonferensi dimana anatara mahasiswa dan dosen bisa tatap lansung via daring dengan mengaktifkan fitur video. Pada kedua aplikasi ini sama-sama memiliki fitur chat dan share screen dimana seluruh peserta bisa langsung melihat materi yang dibawakan oleh dosen namun aplikasi telekonferensi ini memiliki kendala bagi mereka mahasiswa yang bertempat tinggal kurangnya sinyal yang memadahi sehingga berakibat terganggunya proses belajar selain itu, penggunaan telekonferensi seperti google meet tentunya memerlukan kuota yang lumayan besar jika dilaksanakan cukup lama yaitu 2 SKS atau 2 x 50 menit. oleh karena itu perlu memadukan 2 aplikasi sehingga penggunaan kuota bagi mahasiswa tidak terlalu berat. Misalnya, 1 SKS digunakan presentasi materi dengan menggunakan Google meet kemudian 1 SKS selanjutnya menggunakan WAG atau Classroom untuk berdiskusi dan penguatan materi. 


\section{DAFTAR PUSAKA}

Burhanuddin, Chairul Iksan dan Muhammad Nur Abdi. (2020). Ancaman Krisis Ekonomi Global dari Dampak Penyebaran Virus Corona (Covid-19). AkMen Jurnal Ilmiah, 17(1), 90-98.

Daheri, Mirzon., dkk. 2020. Efektifitas WhatsApp sebagai Media Belajar Daring. Jurnal Basicedu: Journal of Elementary Education. 4(4). Hal 775-783

Fuadi, Tuti Marjan., Riki Musriandi., Linda Suryani. 2020. Covid-19: Penerapan Pembelajaran Daring di Perguruan Tinggi :Jurnal Dedikasi Pendidikan, 4 (2).

Hanoatubun, Silpa. 2020. Dampak Covid-19 Terhadap Perekonomian Indonesia. EduPsyCouns Journal. 2 (1)

Harefa, Nelius \& Sumiyati. 2020. Persepsi Siswa Terbadap Google Classroom sebagai LMS pada masa Pandemi Covid-19. Science Education and Application Journal (SEAJ) 2(2).

Indaryani, Eka \& Eka Suliworo. 2018. Dampak pemanfaatan WhatsApp dalam meningkatkan motivasi belajar siswa pada pelajaran fisika. Seminar Nasional Quantum (pp 2477-1511). Yogjakarta: Universitas Ahmad Dahlan

Indiani, Baroroh. 2020. Mengoptimalkan Proses Pembelajaran Dengan Media Daring Pada Masa Pandemi COVID-19. Jurnal Sipatokkong BPSDM Sulawesi Selatan. 1 (3)

Irmawanty., Mohamad Syarif Sumantri., M. Japar.2020. Pendampingan Penulisan Karya Ilmiah (KTI) pada Guru Madrasah Ibtidaiyah secara Online dengan Menggunakan Google Meet. Prosiding Seminar Nasional Pascasarjana Universitas Negeri Jakarta. 1(1).

Kresna, Arief., dan Juni Ahyar. 2020. Pengarub Physical Distancing dan Sosial Distancing Terhadap Kesehatan dalam Pendekatan Linguistik. Jurnal Syntax Tranformation. 1 (4).

Kuntarto, Eko. 2017. Keefektifan Model Pembelajaran Daring dalam Perkuliahan Bahasa Indonesia di Perguruan Tinggi. Journal Indonesian Language Education and Literature. 3 (1).

Kusuma, Jaka Wijaya., dan Hamidah. 2020. Perbandingan Hasil Belajar Matematika dengan Menggunakan Platform Whatapp Grup dan Webinar Zoom dalam Pembelajaran Jarak Jauh pada Masa Pandemik Covid 19. Jurnal Ilmiah Pendidikan Matematika. 5 (1).

Rosita, Nur., Saunir Saun \& Salam Mairi. 2019. Google Classroom for Hybrid Learning in Senior High School. Journal of Learning and Teaching in Digital Age. 5(1)

Sidik, Irwan Fariza., Mohd Mahzan Awang \& Abdul Razaq Ahmad. 2019. The Relationship between Students' Involvement in $21^{\text {st }}$ Century Classroom Learning Activities and Higher Order Thinking Skills. Jurnal Pendidikan Malaysia 44(1).

Wicaksono, M. D. (2020). Pemanfaatan Google Classroom dalam Strategi Pembelajaran Kooperatif pada Mata Pelajaran Ips Kelas VIII. Inspirasi (Jurnal Ilmu-Ilmu sosial),17(1) 
Aziz Kurniawan

Yunus, N. R., \& Rezki, A. 2020. Kebijakan Pemberlakuan Lock Down Sebagai Antisipasi Penyebaran Corona Virus Covid-19. Salam: Jurnal Sosial Dan Budaya Syar-I, 7 (3)

Zhafira, N.H., dkk. 2020. Persepsi Mahasiswa Terhadap Perkuliahan Daring Sebagai Sarana Pembelajaran. Jurnal Bisnis dan Kajian Strategi Manajemen. 4 (1). 